\title{
Learning style and English vocabulary teaching in Higher Educational Establishment
}

\author{
Tsypanova N. " \\ National University of Food Technologies, Kyiv, Ukraine
}

Received: $01.02 .2019 \quad$ Accepted: 10.03 .2019

\begin{abstract}
The article deals with the usage of the most up-to-date methods in English vocabulary teaching. It demonstrates how a teacher should use additional means of teaching for better efficiency. The clue concepts the article dwells upon are learning styles and auxiliary aids. The background of the research is rapidly growing number of English neologisms creating the need for more effective vocabulary teaching techniques. The article is aimed at teachers of higher education establishment willing to improve their work and diversify educational process. The purpose of this research is to provide teachers with powerful approach to English vocabulary teaching using appropriate auxiliary aids. The applied method of the research is comparative analysis of educational performance of students when applying auxiliary aids of particular type and combination of auxiliary aids of different types. As of the basis of the research it employs author's personal experience as teacher at higher education establishment. The article provides the definition of auxiliary aids of study and explains how to use them in vocabulary teaching. Auxiliary aids are considered to be a powerful means used to increase the effectiveness of conventional means of vocabulary teaching. The author of the article concentrates on different learning styles and ways the students consume given information (visual, audial and kinesthetic). Examples of how learning styles are combined when teaching students at higher educational facilities are provided as well as some everyday tips for teachers on the best practices in vocabulary teaching. They can be introduced and widely used in higher education establishment for students of English as foreign language with any level of English proficiency. That is the most powerful side of those practices they are intentionally designed to be as universal as possible. It makes them widely applicable; teachers can also modify them in the way they see to be the best in their particular case. The integration of visual, audial and kinesthetic method of teaching by combining appropriate auxiliary aids is one of the most effective ways of teaching foreign vocabulary. The combination of different channels of perception provides the best results when memorizing and at the same time enhances student's intellect by intensifying brain activity.
\end{abstract}

Key words: auxiliary aids, learning style, learning style combination.

\section{Способи сприйняття і навчання англійської лексики у вищому навчальному закладі}

\author{
Ципанова Н. Я. \\ Національний Університет Харчових Технологій, Київ, Україна
}

\begin{abstract}
Анотація. В даній статті розглядається використання найбільш сучасних методів навчання англійської лексики у вищому навчальному закладі. Показано, як викладач має використовувати додаткові засоби навчання для досягнення найкращого результату. Підгрунтям дослідження $є$ велика кількість неологізмів, які щорічно поповнюють словник англійської мови, а отже і необхідність прискореного навчання лексики. Ключовими концепціями статті $є$ способи сприйняття і додаткові засоби навчання. Стаття призначена для викладачів вищих навчальних закладів, що бажають покращити навчальний процес і зробити його більш різноманітним. Метою дослідження є вироблення правильного підходу до навчання англійської лексики за допомогою поєднання додаткових засобів навчання. У дослідженні використовувався метод порівняння ефективності навчання учнів з використанням додаткових засобів і без них. В якості основи використовується власний досвід викладання англійської мови у вищому навчальному закладі. У статті дається визначення допоміжних засобів і пояснюється, як їх використовувати у навчанні англійської лексики для розширення словникового запасу. Допоміжні засоби вважаються потужним засобом підвищення ефективності традиційних засобів навчання лексики. Автор зосереджується на різних видах сприйняття та способах, якими студенти
\end{abstract}

Corresponding Author: Tsypanova Nataliia Yaroslavivna. Phone: +38(068)5510711. E-mail: nataliia.tsypanova@ukr.net National University of Food Technologies, vul. Volodymyrska, 68, Kyiv, Ukraine, 01033.

Biдnовідальний автор: Ципанова Наталія Ярославівна. Тел. +38(068)5510711. E-mail: nataliia.tsypanova@ukr.net Київський Національний Університет Харчових Технологій, вул. Володимирська, 68, м. Київ, Україна, 01033 
сприймають подану інформацію (візуальні, слухові та кінестетичні). Наведені приклади того, як стилі навчання об'єднуються під час навчання студентів нефілологічних спеціальностей у вищому навчальному закладі, а також деякі поради для викладачів щодо кращих практик навчання лексики. Їх можна запровадити і широко використовувати для студентів з будь-яким рівнем володіння англійською мовою. Це найпотужніша сторона цих практик - вони створені для того щоб бути максимально універсальними. Це значно розширює їх область застосування, викладачі також можуть модифікувати їх так, як вони вважають за потрібне у своєму конкретному випадку. Об'єднання візуальних, аудіальних і кінестетичних способів через поєднання відповідних допоміжних засобів навчання $€$ одним з найбільш ефективних способів викладання іноземної лексики. Поєднання різних каналів сприйняття забезпечує найкращі результати при запам'ятовуванні і одночасно розвиває інтелект шляхом інтенсифікації роботи мозку.

Ключові слова: додаткові засоби, способи сприйняття, поєднання способів сприйняття.

\title{
Способы восприятия и обучение английской лексике у высшем учебном заведении
}

\author{
Цыпанова Н. Я. \\ Национальный Университет Пищевых Технологий, Киев, Украина
}

\begin{abstract}
Аннотация. В данной статье рассматривается использование наиболее современных методов обучения английской лексики в высшей школе. Показано, как преподаватель должен использовать вспомогательные средства обучения для достижения наилучшего результата. Мотивацией исследования является большое количество неологизмов, которые ежегодно пополняют словарь английского языка, а, следовательно, и необходимость ускоренного обучения студентов новой лексике. Ключевыми концепциями статьи являются способы восприятия и дополнительные средства обучения. Статья предназначена для преподавателей высшей школы, желающих улучшить учебный процесс и сделать его более разнообразным. Целью исследования является выработка правильного подхода к обучению английской лексики с помощью вспомогательных средств обучения. В исследовании использовался метод сравнения эффрективности обучения учащихся с использованием вспомогательных средств и без них. В качестве основы используется собственный опыт преподавания английского языка в высшей школе. В статье дается определение вспомогательных средств и объясняется, как их использовать в обучении английской лексике для расширения словарного запаса. Вспомогательные средства считаются мощным средством повышения эфффективности традиционных средств обучения лексике. Автор сосредотачивается на различных видах восприятия и способах, которыми ученики воспринимают представленную информацию (визуальные, слуховые и кинестетические). Приведенные примеры того, как способы восприятия объединяются при обучении учащихся в ВУЗе, а также даются некоторые советы для преподавателей по использованию практик обучения лексики. Их можно ввести и широко использовать в высшем учебном заведении для студентов с любым уровнем владения английским языком. Это самая мощная сторона этих практик - они созданы для того чтобы быть максимально универсальными. Это значительно расширяет их область применения, преподаватели также могут модифицировать их так, как они считают нужным в своем конкретном случае. Объединение визуальных, аудиальных и кинестетических способов путём сочетание соответствующих вспомогательных средств обучения является одним из наиболее эффеективных способов преподавания иностранного лексики. Сочетание различных каналов восприятия обеспечивает лучшие результаты при запоминании и одновременно развивает интеллект путем интенсификации работы мозга.

Ключевые слова: дополнительные средства, способы восприятия, сочетание способов восприятия.
\end{abstract}

\section{Bcmyn}

Протягом усієї історії англійської мови її словниковий запас постійно розширювався, ставши найбільшим серед всіх людських мов. Навіть сьогодні щорічно близько 800 неологізмів додаються до словнику англійської мови. Структура англійської, а саме порівняно проста структура граматичної системи, демонструє важливість словника в англійському спілкуванні порівняно з іншими мовами 3 більш складною граматикою. Також соціальний, економічний і технологічний розвиток людської цивілізації викликав швидке зростання об'єму лексики. Сотні неологізмів широко використовуються щодня, щоб визначити поняття, яких не існувало ще сто років тому. Активно вживана лексика середнього мовця стрімко розширюється, що робить необхідним включення більшої кількості виразів у навчальні плани вивчення іноземної мови. У той же час міжкультурне спілкування вимагає додаткових знань про специфічні для певної культури вирази, що використовуються особами, які належать до цієї культури, і говорять англійською мовою як іноземною. 
Спосіб сприйняття - це термін, який звичайно використовується для опису природного або звичного способу отримання та обробки інформації в навчальних ситуаціях. Простіше кажучи, спосіб сприйняття описує те, як люди отримують та запам'ятовують інформацію під час навчання [6]. Термін «допоміжні засоби» вводиться в цій статті для позначення всього обсягу додаткових засобів, що використовуються в навчанні словникового запасу. До них відносяться візуальні, аудіальні та кінестетичні засоби, які застосовуються в цілісності з однією і тією ж метою і в процесі навчання. Домінуючі способи сприйняття студентів тісно пов'язані з допоміжними засобами і регулюють співвідношення візуальних, аудіальних і кінестетичних засобів в рамках комплексу допоміжних засобів.

Ось чому вважають, що навчання лексики $€$ найважливішою частиною сучасного викладання англійської мови. Кількість висловлювань, що використовуються в повсякденному житті і в спеціальних сфрерах людської діяльності, зростає, а словник англійської мови середнього мовця повинен задовольняти зростаючим потребам. Ця стаття доводить необхідність докорінно нового підходу до викладання лексики та демонструє кілька прикладів їх практичного застосування.

Мета дослідження - з'ясувати, як поєднувати способи сприйняття для найбільш ефективного навчання англійської лексики

\section{II Матеріал і методи дослідження}

Тема моєї статті була розглянута раніше в дослідженнях[19], проведених Ентоні Граша [8, с. 123124], Ріта і Кеннет Данн [6] і Дуглас Маккой [7].

Питаннями відбору лексичного мінімуму займалися видатні методисти. Серед них Торндайк (Thorndike) [7] та Хорн (Horn) [11] в США, Палмер (H. Palmer) у Японії, Вест (M. West) у Індії, Ричардз (E. Richards) та Огден (C. K. Ogden) у Англії, І. В. Рахманов у Росії та багато інших, які вважали, що відібрані до лексичного мінімуму слова мають:

1) часто вживатися у мові (частотність визначається математично за допомогою статистичних даних);

2) легко комбінуватися з іншими словами (e.g. nice room, nice girl, nice weather);

3) бути нелімітованими з точки зору стилю;

4) входити до тем, визначених програмою;

5) бути цінними з точки зору словоутворення (e.g. use, used, useful, useless, usefully, user, usage).

На думку провідних українських дослідників (С. Ю. Ніколаєва [3], О. Б. Бігич [1], Н. К. Скляренко та інш.), основними критеріями відбору лексичного мінімуму є:

1) сполучуваність лексичної одиниці (ЛО) з іншими одиницями у мовленні;

2) семантична цінність (відображення ЛО важливих понять в різних сферах людської діяльності);

3) стилістична необмеженість (вживання ЛО в різних стилях).

Додатковими критеріями відбору лексичного мінімуму є:

1) ччастотність;

2) багатозначність ЛО;

3) словотворча здатність ЛО.

Для того, щоб ефективно викладати, викладач вищого навчального закладу повинен враховувати певні особливості сприйняття людини та способи сприйняття. Кожна людина за своєю природою відрізняється і тому вимагає індивідуального підходу в навчанні для досягнення задовільних результатів. Для того, щоб забезпечити студента індивідуальним підходом, викладач повинен зрозуміти різницю між психологічними особливостями навчання та способами сприйняття. Можливо, найбільш поширеною і широко використовуваною [4] категоризацією різних способів сприйняття $є$ модель VARK Флемінга (іноді VAK), яка розширюється на попередніх моделях нейролінгвістичного програмування (VARK):

- візуали;

- аудіали;

- кінестетики. 
Флемінг стверджував, що візуальні учні мають краще сприймають інформацію очами (думати на знімках; наочні посібники, такі як накладні слайди, діаграми, роздачі тощо). Аудіальний учень найкраще навчається через слухання (лекції, дискусії, касети тощо). Тактильний / кінестетичний студент вважає за краще вчитися за допомогою досвіду - переміщення, дотик і виконання (активне дослідження світу; наукові проекти; експерименти тощо). Його використання в педагогіці дозволяє викладачам підготувати класи, які стосуються кожної з цих сфрер. Студенти також можуть використовувати модель для визначення свого бажаного способу сприйняття та максимізації свого освітнього досвіду, зосередившись на способі, що найбільше допомагає саме їм.

Деякі психологи і неврологи ставили під сумнів наукову основу і теорії, на яких вони ґрунтуються. На думку Сьюзан Грінфрілд, практика є «нісенітницею» з нейронаукової точки зору: «Люди розвивалися, щоб побудувати картину світу через наші почуття, працюючи в унісон, використовуючи величезну кількість взаємозв'язків, що існує в мозку».

Пізніше було доведено [5], що, незважаючи на те, що студент надає перевагу одному способу сприйняття над іншими, найкращий результат досягається тоді, коли він залучає всі свої сенсорні рецептори протягом отримування і запам'ятовування інформації. Найвищий рівень когерентності називається синестезією, яка $€$ неврологічним станом, при якому стимуляція сенсорного або когнітивного шляху призводить до автоматичних, мимовільних переживань у другому сенсорному або когнітивному шляху [16]. Це, безумовно, найбільш яскравий прояв синестезії, який демонструють лише унікальні та надзвичайно обдаровані особи. Зазвичай люди проявляють синестезію у вигляді сильних психічних зв'язків між аудіальними, візуальними або кін естетичним образом певного об'єкта, дії або абстрактного поняття.

\section{III Результати}

Для початку в цій статті представляється визначення допоміжних засобів. Вони позначають весь набір візуальних, аудіальних і кінестетичних засобів навчання, що застосовуються в навчанні як доповнення до стандартних засобів (підручник, книга для вправ, компакт-диск, тощо). У даному визначенні наголошується на наборі слів, демонструючи, що допоміжні засоби використовуються як цілісність.

3 огляду на вище зазначене, найбільш ефективним і швидким способом навчання словникового запасу є використання візуальних, аудіальних і кінестетичних засобів для того, щоб змусити студентів сприймати знання, застосовуючи всі свої сенсорні рецептори. Основна ідея цього підходу полягає в поєднанні візуальних, аудіальних і кінестетичних образів слова, сполучення слів або виразу для більш стійкого запам'ятовування. Одночасне застосування різних каналів сприйняття змушує мозок працювати більш ефективно, розвиваючи таким чином пам'ять, інтелект та пізнавальні здібностей студентів. Ключ до ефективного навчання - це не тільки використання всіх допоміжних засобів, але й їх комбінацій.

Таким чином, допоміжні засоби включають поєднання візуальних, аудіальних і кінестетичних засобів. Візуальні допоміжні засоби, які визначаються як ілюстративний елемент, наприклад фільм, слайд, або модель, призначені для доповнення розмовної інформації таким чином, щоб їі можна було зрозуміти легше. Це - будь-який об'єкт або картина, що відноситься до предмету, що вивчається. Візуальні допоміжні засоби - це те, що ви приносите для підтримки будь-якого проекту або звіту, який ви обговорюєте. Це дає слухачеві щось конкретне, щоб подивитися, щоб краще зрозуміти, про що ви говорите.

Важливо використовувати метод стимуляції для навчання студентів [8],[10]. Використання наочних посібників може зробити наш урок більш цікавим і ефективним. Коли студенти можуть почути і побачити те, що ви говорите, вони краще засвоюють цю інформацію. Візуальні засоби не тільки фокусують увагу, вони підкріплюють ваші слова.

Використання візуальних засобів під час практичних занять допомагає студентам, які більш схильні до вивчення зором, більше зацікавитися предметом. $€$ візуальні засоби для студентів різного віку, які підходять для використання в класі. Візуальні засоби мають бути ефективним інструментом для навчання предмету і використовуються на додаток до регулярного плану практичного заняття у вищому навчальному закладі. 
Аудіальні засоби легко поєднуються з візуальними, наприклад, у фільмах та слайд-шоу із звуковим супроводом.

Як, приклад вправи, що поєднує різні допоміжні засоби, демонструється той, який використовувався під час практичної підготовки студентів другого курсу нефілологічних спеціальностей. Викладаючи ділову англійську мову використовувався навчальний комплект «Telephone» by John Hughes, оскільки він надає різноманітність аудіальних і наочних засобів для навчання лексики. Кожне заняття починалося з вправи з ключовими словами та виразами.

Для того, щоб об'єднати всі допоміжні засоби, робилося картки з картинками з посібника для вчителя. Кожна карта об'єднала картинку, що позначає деякий об'єкт, і його назву написано на іншій стороні картки. Поєднання зображень і слів дозволило уникнути використання української мови для перекладу слів. Потім я використовували стандартні аудіодоріжки з компакт-дискупосібника для вчителя одночасно з використанням карт. Коли студенти взяли картки, вони почули вимову слова, яке водночас бачили на картинці. Потім вони повернули картку і побачили, як це слово пишеться.

Таким чином, об'єднувалося аудіальні (вимова слова), візуальні (зображення, що позначають слова) і кінестетичні (картонні картки і їхні повороти) допоміжні засоби,роблячи викладання словникового запасу більш ефективним.

Використання фрлеш-карток є ефективним методом для:

1. Вивчення графічної форми слів.

2. Запам'ятовування лексичного значення.

3. Швидкого мовного відтворення слова (читання).

4. Переходу слів з пасивного словникового запасу в активний (використання в говорінні).

5. Підвищення мотивації до вивчення іноземної мови.

Інший приклад вправи стосується застосування допоміжних засобів у рольових іграх. Наприклад, під час навчання лексики для бізнес зустрічей та переговорів розділялося групу (10 студентів) на п'ять пар, і кожна з них отримувала таємне завдання. Основна ідея кожного завдання полягала в тому, щоб продемонструвати вміння вести бізнес зустрічі та переговори. Група, що мала практику бізнес переговорів поділилися своїм досвідом. Інша група, пара хлопчиків, продемонструвала короткий фрільм, завантажений на YouTube, демонструючи, як потрібно себе вести під час бізнес переговорів, дрес-код. Потім вони пояснили деякі особливі терміни, сталі вирази, які потрібно вживати під час переговорів. Після демонстрації інші студенти задавали питання і висловлювали свою думку щодо обговорюваної теми.

Таким чином були об'єднані дії, наочні посібники та спілкування в одну вправу з елементами рольової гри. Результатом такого застосування було сильне запам'ятовування більшості лексичних одиниць, що надаються під час дослідження, та ефективність їх використання під час занять діловою іноземною мовою. Слабким моментом мого методу $€$ те, що практично неможливо відрегулювати співвідношення окремих методів у всьому масштабі як результат різних стилів навчання студентів у групі; результат також змінюється в залежності від домінуючого способу сприйняття в групі. Тим не менш, важливим моментом $€$ те, що всі вправи включають в себе всі стилі навчання і втягують більше нервових центрів в мозок, що робить запам'ятовування більш швидким і ефективним.

Одним із найбільш використовуваних методів для запам'ятовування лексики іноземної мови на заняттях із студентами немовних спеціальностей є метод інтелект-карток (Mind Maps). Інтелект-карти це розробка Тоні Бьюзена - відомого письменника, лектора і консультанта з питань інтелекту, психології навчання і проблем мислення. Карта пам'яті Mind Мар виступає альтернативою традиційним способам обробки і передачі інформації (конспектами, коротким записам, схемами і т.п.) Ця альтернатива більш продуктивна, так як має природну психологічну основу, а головне перетворює студента в активного творця власного знання.

Переваги ментальних карт:

1) зручні у використанні;

2) показують зв'язки між явищами, логіку мислення;

3) сприяють кращому запам'ятовуванню інформації;

4) збирають воєдино велику кількість даних;

5) розвивають креативність, мислення. 
Дуже добре працює при введенні нового граматичного матеріалу. Що стосується лексики, викладач використовують цей прийом у груповій роботі на етапі закріплення пройденого лексичного матеріалу з певної теми.

Викладачі Національного університету харчових технологій часто на заняттях ділової іноземної мови використовують ментальні карти для вивчення лексичних одиниць. Для вивчення теми «Структура компанії» та лексичних одиниць [7], які відносяться до різних відділів використовується така ментальна карта (рис.1).

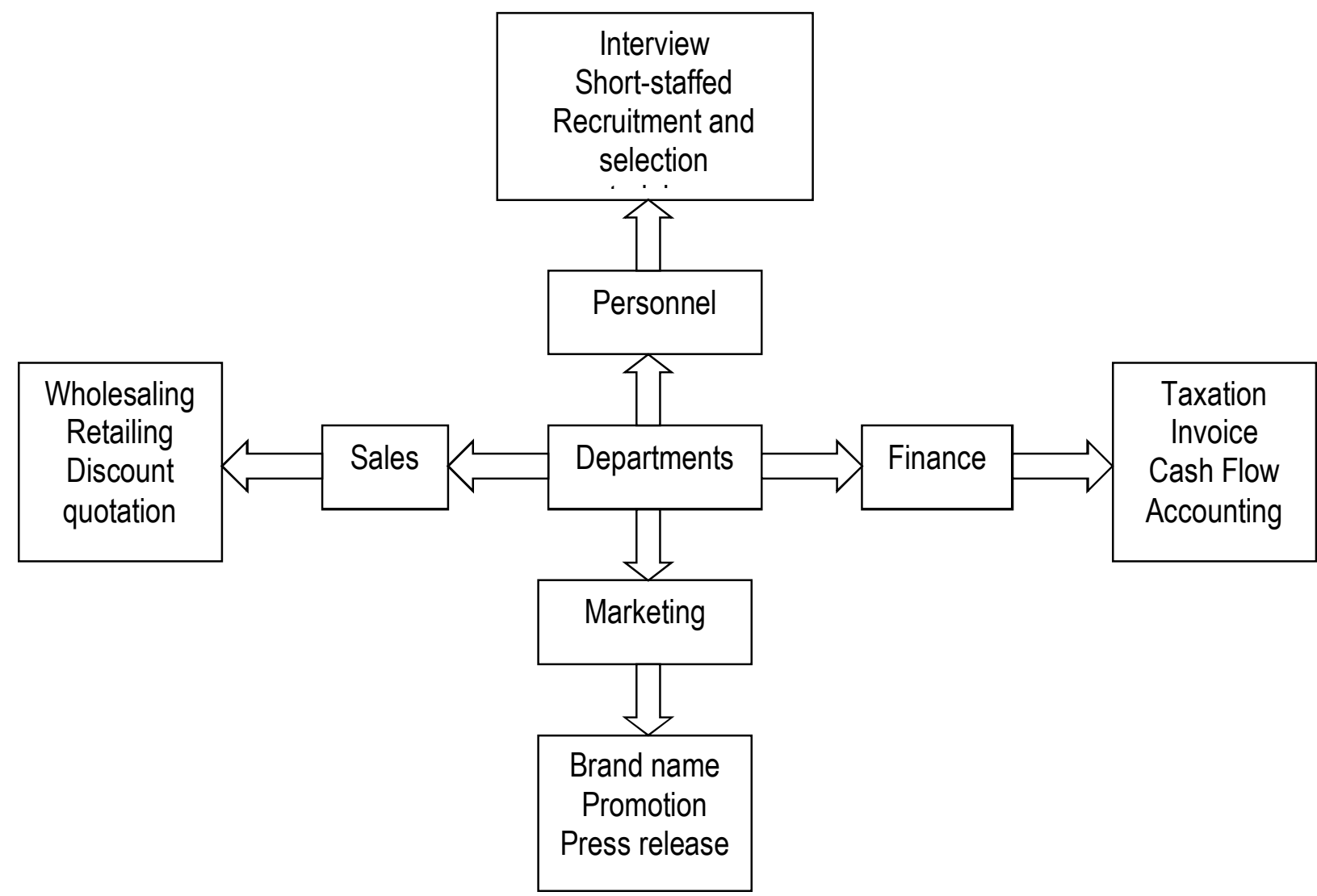

Рис. 1. Ментальна карта для вивчення лексичних одиниць з теми «Структура компанії» для студентів 3 курсу Національного університету харчових технологій

Щоб зняти напругу під час заняття іноземною мовою, переключити увагу студентів та викликати позитивні емоції використовується метод вивчення лексики за допомогою пісень. Завдання 3 пропусками можна використовувати при роботі з віршами або текстами пісень. Принциповим моментом тут є використання автентичного мовного зразка, і тут пісні і вірші мають багато переваг перед прозовим матеріалом. Вони легко вводяться, легко запам'ятовуються, співати можна хором, що знімає психологічний прес з невпевнених у собі учнів. У справжньому пісенному матеріалі часто зустрічаються цілі фрази і окремі лексичні одиниці, характерні саме для розмовної мови.

\section{IV Обговорення}

Розглядаючи статтю Сіньхуа Юаня «Review of Exploring spoken English learner language using corpora: Learnertalk» [17] можна відмітити використання обчислювальної техніки для ознайомлення студентів з автентичною мовою навіть за відсутності можливості спілкування с носіями мови. Поєднання сприйняття на слух інформації з аудіо записів та одночасна демонстрація об'єкту, що описується покращує запам'ятовування та звільнює від необхідності запису та читання транскрипції. Повторюваність та відтворюваність відеороликів дає змогу доносити навчальний матеріал студентам, що пропустили заняття. 
Зв'язок між стилями навчання, способами сприйняття та навчанням англійської лексики розглядається у статті іранських викладачів Саіда Алі Остовар-Намагі і Акрама Малекпура «Vocabulary Learning Strategies from the Bottom-Up: A Grounded Theory» [13].

Через високий поріг вступних іспитів до університету в Ірані саме лексика найчастіше є найбільш нагальною потребою у студентів, які вивчають англійську мову в державних вузах Ірану. Це зумовлює актуальність її вивчення.

Аналіз показує, що до співбесід іранські студенти, що вивчають англійську як іноземну мову,переважно не знали про стратегії навчання, тому що стратегія навчання не посідає належного місця в іранській системі мовної освіти. Діалогічний процес співбесіди, однак, дав їм можливість поміркувати над своїм досвідом вивчення словникового запасу та розказати про їх досвід. Найчастіше опис досвіду студентів та концептуалізація досвіду вивчення лексики мають перевагу над теоретично обґрунтованими висновки, оскільки вони дають читачам глибоке розуміння того, як студенти вивчають словниковий запас, замість спущених зверху вниз групою вчених указівок, які виражені у формі запитань, що підлягають адмініструванню і перевіряються за допомогою кількісних оцінок.

Епістемологічно, стратегії вивчення лексики повинні розроблятися скоріше знизу вверх, а не навпаки,тобто, вони повинні бути концептуалізацією поглядів і досвіду учнів, а не розробленими педагогами і накладеними на навчальну практику через прикладну педагогічну модель. Таким чином, висновки цього дослідження доповнюють базис знань стратегій навчання лексики, оскільки вони представляють практичний досвід з глибоким розуміння того, що відбувається в процесі лексичного розвитку, і який доповнює узагальнюючі стратегії, виведених з кількісних досліджень. Більше того, результати чітко показують, що іранські студенти, що вивчають англійську як іноземну мову,використовують обмежену кількість стратегій; отже, їх лексична некомпетентність може бути пов'язана з їх обмеженим знанням і невикористанням стратегій навчання лексики. Нарешті, як показують результати дослідження, стратегії, які знають і використовують учні, були розроблені самими учнями. Іншими словами, навчання стратегії вивчення лексики в значній мірі ігнорується в мовній освіті Ірану[18].

Підводячи підсумок, більшість іранських студентів, що вивчають англійську як іноземну мову,вважають навчання лексики складним та таким, що їх лякає. Причина полягає в тому, що вони володіють обмеженими знаннями стратегії вивчення лексики. Іншими словами, лексичний дефріцит учнів пов'язаний із дефріцитом їх стратегій навчання. Щоб виправити цю ситуацію в освіті, практикуючі працівники, педагоги та особи, що визначають політику в освіті, повинні брати участь у навчанні стратегій як невід'ємної частини мовної освіти. Це не тільки покращує лексичну компетентність студентів, а й вона також спрямовує їх до навчальної автономії[20].

\section{V Висновки}

Активний словник англійської мови постійно розширюється, що викликає необхідність більш ефрективного викладання лексики. Це, в свою чергу, передбачає глибоке розуміння того, як люди вивчають та сприймають інформацію.

Існують три основні способи навчання - візуальний, аудіальний і кінестетичний. Що стосується окремої людини, то один з цих стилів зазвичай домінує і визначає найпростіший спосіб сприйняття інформації.

Вважається, що поєднання візуальних, аудіальних і кін естетичних способів через поєднання відповідних допоміжних засобів навчання є одним з найбільш ефективних способів викладання лексики. Воно включає в себе кілька сенсорних рецепторів у навчанні і, таким чином, здається більш ефективним, ніж окремі компоненти. Поєднання різних каналів сприйняття забезпечує найкращі результати при запам'ятовуванні і одночасно розвиває інтелект, шляхом інтенсифікації роботи мозкух[14]. Тема моєї статті $\epsilon$ актуальною, оскільки лексика середнього мовця, що використовує англійську, постійно зростає і, вимагаючи таким чином від мовця багатшого словникового запасу, та більш прискореного його вивчення. Роль англійської мови не зменшиться в найближчому майбутньому, а навчання англійської мови все ще користується попитом. Було доведено, що наступний крок у вивченні лексики буде тісно пов'язаний з методами, які забезпечують викладання мовних шаблонів, 
широко використовуваних у повсякденній комунікації, а також викладання словника, зосередженого на регіональних стандартах англійської мови.

\section{Бібліограффічні посилання}

[1] Бігич О. Б. Методика фрормування іншомовної компетентності в аудіюванні / Іноземні мови. 2012. № 2. С. 19-30.

[2] Кузнецова Т. М. Этапы работы над словом (Из опыта работы над лексикой) / ИЯШ. 5/91. С. 88-94.

[3] Ніколаєва С. Ю. Методика навчання іноземних мов у середніх навчальних закладах. К.: Ленвіт, 1999. 320 с.

[4] Curry L. One critique of the research on learning styles / Educational Leadership. Alexandria, VA, 1990. Vol. 48. №2. P. 5056.

[5] Grasha A. F. Teaching with Style: A practical guide to enhancing learning by understanding teaching and learning styles. Pittsburgh, PA: Alliance Publishers. 1996. 234 p.

[6] Leite Walter L, Svinicki Marilla, Shi Yuying. Attempted Validation of the Scores of the VARK: Learning Styles Inventory With Multitrait - Multimethod Confirmatory Factor Analysis Models / Educational and Psychological Measurement. SAGE Publications. Thousand Oaks, CA, 2009. Vol. 70. №2. P. 323-339.

[7] McCoy, Douglas. Visuals and Vocabulary: The Order of Presentation Matters / Learning vocabulary in another language. Cambridge: Cambridge University Press. 2007. Vol. 25. №1. P. 21-32.

[8] Micán, Adriana Duque, Medina, Liliana Cuesta. Boosting vocabulary learning through self-assessment in an English language teaching context. Assessment \& Evaluation in Higher Education, 2015, 42 (3), 398-414. doi: https://doi.org/10.1080/02602938.2015.1118433

[9] Pike, Mark A. Ethical English. Teaching and learning in English as spiritual, moral and religious education. Bloomsbury, Academic. 2015. doi: https://doi.org/10.5040/9781472593412.ch-005

[10] Rahman, Marita Lailia Self Management on Self Directed Learning in Learning English Vocabulary. Proceedings of the International Conference on English Language Teaching, 2018, 145, 156-158. doi: https://doi.org/10.2991/iconelt-17.2018.35

[11] Robert E. HornVisual Language: Global Communication for the 21st Century, 1998. $270 \mathrm{p}$.

[12] Schmitt, N. Current Perspectives on Vocabulary Teaching and Learning. International Handbook of English Language Teaching, Springer International Handbooks of Education, 2003. doi: https://doi.org/10.1007/978-0-387-46301-8_55

[13] Seyyed Ali Ostovar-Namaghi, AkramMalekpur. Vocabulary Learning Strategies from the Bottom-Up: A Grounded Theory. 2015. Volume 15(2). P. 235-251.

[14] Tight, Daniel G. (2010). Perceptual Learning Style Matching and L2 Vocabulary Acquisition. Language Learning, 60(4), 792833. doi: https://doi.org/10.1111/j.1467-9922.2010.00572.x

[15] Wai-man, Florence Yip. Online vocabulary games as a tool for teaching and learning English vocabulary 2003. doi: https://doi.org/10.5353/th_b2959751

[16] Williams Pharrell. Synesthetes: People of the Future. URL: https://www.psychologytoday.com/ blog/ sensorium/ 201203/synesthetes-people-the-future (дата звернення 25.01.2019)

[17] Xinhua Yuan. Exploring spoken English learner language using corpora: Learner talk / Language Learning \& Technology. 2018. Volume 22(3). P.41-44.

[18] Yip, Florence W. M. Kwan, Alvin C. M. Online vocabulary games as a tool for teaching and learning English vocabulary. Educational Media International, 2006, 43(3), 233-249. doi: https://doi.org/10.1080/09523980600641445

[19] Zheng, Shigao. Studies and Suggestions on English Vocabulary Teaching and Learning. English Language Teaching, 5 (5), 2012, 129-137. doi: https://doi.org/10.5539/elt.v5n5p129

[20] Zokaee, S., Zaferanieh, E., Naseri, M. On the Impacts of Perceptual Learning Style and Gender on Iranian Undergraduate EFL Learners' Choice of Vocabulary Learning Strategies. English Language Teaching, 5(9), 2012, 138-143. doi: https://doi.org/10.5539/elt.v5n9p138

\section{References}

[1] Bihych, O. B. (2012). Metodyka formuvannia inshomovnoi kompetentnosti v audiuvanni. Inozemni movy, № 2, 19-30. [in Ukrainian]

[2] Kuznetsova, T. M. (1990). Etapy raboty nad slovom, IYASH, 5/91, 88-94.[in Russian]

[3] Nikolaieva, S. lu. (1999). Metodyka navchannia inozemnykh mov u serednikhnavchalnykhzakladakh. Lenvit, Kyiv, Ukraine, 320. [in Ukrainian]

[4] Curry, L. (1990). One critique of the research on learning styles / Educational Leadership. Alexandria, VA, 48(2), 50-56.

[5] Grasha, A. F. (1996). Teaching with Style: A practical guide to enhancing learning by understanding teaching and learning styles. Pittsburgh, PA: Alliance Publishers, 234.

[6] Leite, Walter L, Svinicki, Marilla, Shi, Yuying (2009). Attempted Validation of the Scores of the VARK: Learning Styles Inventory With Multitrait - Multimethod Confirmatory Factor Analysis Models. Educational and Psychological Measurement. SAGE Publications, Thousand Oaks, CA, 70(2), 323-339.

[7] McCoy, Douglas (2007). Visuals and Vocabulary: The Order of Presentation Matters. Learning vocabulary in another language. Cambridge: Cambridge University Press, 2007, 25(1), 21-32. 
[8] Micán, Adriana Duque, Medina, Liliana Cuesta (2015). Boosting vocabulary learning through self-assessment in an English language teaching context. Assessment \& Evaluation in Higher Education, 42 (3), 398-414. doi: https://doi.org/10.1080/02602938.2015.1118433

[9] Pike, Mark A. (2015). Ethical English. Teaching and learning in English as spiritual, moral and religious education. Bloomsbury, Academic. doi: https://doi.org/10.5040/9781472593412.ch-005

[10] Rahman, Marita Lailia (2018). Self Management on Self Directed Learning in Learning English Vocabulary. Proceedings of the International Conference on English Language Teaching, 145, 156-158. doi: https://doi.org/10.2991/iconelt-17.2018.35

[11] Robert E. HornVisual Language: Global Communication for the 21st Century, 1998, $270 \mathrm{p}$.

[12] Schmitt, N. (2003).Current Perspectives on Vocabulary Teaching and Learning. International Handbook of English Language Teaching, Springer International Handbooks of Education. doi: https://doi.org/10.1007/978-0-387-46301-8 55

[13] Seyyed Ali Ostovar-Namaghi, AkramMalekpur (2015). Vocabulary Learning Strategies from the Bottom-Up: A Grounded Theory, 15(2), 235-251.

[14] Tight, Daniel G. (2010). Perceptual Learning Style Matching and L2 Vocabulary Acquisition. Language Learning, 60(4), 792833. doi: https://doi.org/10.1111/j.1467-9922.2010.00572.x

[15] Wai-man, Florence Yip (2003). Online vocabulary games as a tool for teaching and learning English vocabulary. doi: https://doi.org/10.5353/th_b2959751

[16] Williams Pharrell. Synesthetes: People of the Future. URL: https://www.psychologytoday.com/ blog/ sensorium/ 201203/synesthetes-people-the-future (дата звернення 25.01.2019)

[17] Xinhua Yuan. Exploring spoken English learner language using corpora: Learner talk. Language Learning \& Technology, 22(3), 41-44.

[18] Yip, Florence W. M. Kwan, Alvin C. M. (2006). Online vocabulary games as a tool for teaching and learning English vocabulary. Educational Media International, 43(3), 233-249. doi: https://doi.org/10.1080/09523980600641445

[19] Zheng, Shigao (2012). Studies and Suggestions on English Vocabulary Teaching and Learning. English Language Teaching, 5 (5), 129-137. doi: https://doi.org/10.5539/elt.v5n5p129

[20] Zokaee, S., Zaferanieh, E., Naseri, M. (2012). On the Impacts of Perceptual Learning Style and Gender on Iranian Undergraduate EFL Learners' Choice of Vocabulary Learning Strategies. English Language Teaching, 5(9), 138-143. doi: https://doi.org/10.5539/elt.v5n9p138.

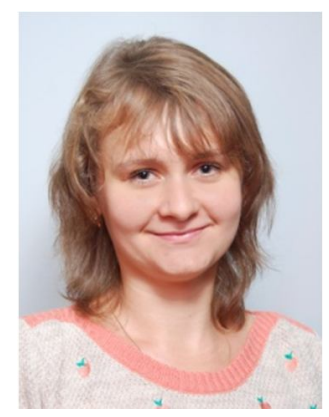

Ципанова Наталія Ярославівна.

Викладач кафедри ділової іноземної мови та міжнародної комунікації, Київський Національний Університет Харчових Технологій,

вул. Володимирська, 68, м. Київ, Україна, 01033.

Тел. +38(068)5510711. E-mail: nataliia.tsypanova@ukr.net

Tsypanova Nataliia Yaroslavivna.

English Language Tutor of The Department Of Business Foreign Language, National University of Food Technologies,

vul. Volodymyrska, 68, Kyiv, Ukraine, 01033.

Phone: +38(068)5510711. E-mail: nataliia.tsypanova@ukr.net

ORCID: 0000-0001-8185-2106

Researcher ID: D-2706-2019

\section{Citation (APA):}

Tsypanova, N. (2019). Learning style and English vocabulary teaching in Higher Educational Establishment. Engineering and Educational Technologies, 7 (1), 18-26. doi: https://doi.org/10.30929/2307-9770.2019.07.01.02

\section{Цитування (ДСТУ 8302:2015):}

Ципанова Н. Я. Способи сприйняття і навчання англійської лексики у вищому навчальному закладі / Інженерні та освітні технології. 2019. Т. 7. № 1. С. 18-26. doi: https://doi.org/10.30929/2307-9770.2019.07.01.02

Обсяг статmi: $\quad$ сторінок - 9 ; умовних друк. аркушів - 1,034. 